\title{
Personalization of Politics Between Television and the Internet: Leader Effects in the 2013 Italian Parliamentary Election
}

\section{Diego Garzia}

To cite this article: Diego Garzia (2017) Personalization of Politics Between Television and the Internet: Leader Effects in the 2013 Italian Parliamentary Election, Journal of Information Technology \& Politics, 14:4, 403-416, DOI: 10.1080/19331681.2017.1365265

To link to this article: https://doi.org/10.1080/19331681.2017.1365265

曲 Published online: 02 Nov 2017.

Submit your article to this journal

山 Article views: 523

Q View related articles $\sqsubset$

View Crossmark data \lceil

Citing articles: 7 View citing articles ־ 


\title{
Personalization of Politics Between Television and the Internet: Leader Effects in the 2013 Italian Parliamentary Election
}

\author{
Diego Garzia
}

\section{ABSTRACT}

This paper provides an empirical assessment of the relationship between media exposure and leader effects on voting through an analysis of Italy--an ideal case for the study of the personalization of politics and its connection with political communication. The results show the dominance of leader effects among voters strongly exposed to television and a somewhat differentiated impact on Internauts. By looking at leader effects across different audiences, this paper elaborates on the missing link between electoral research and political communication, and it eventually speaks to the broader question of how important media is for the outcome of contemporary democratic elections.

\section{KEYWORDS}

ICTs; leader effects; media exposure; personalization of politics; voting behavior

\section{Introduction}

In recent years, a growing amount of academic research has been devoted to the increasingly tighter relationship between personality and politics (for a review, see: McAllister, 2007). According to Rahat and Sheafer (2007), the process of personalization of politics entails that "the political weight of the individual actor in the political process increases over time, while the centrality of the political group (i.e., political party) declines" (Rahat \& Sheafer, 2007, p. 65). In a similar vein, both Karvonen (2010, p. 4) and Swanson and Mancini (1996, p. 10) put forward the notion that individual politicians have become more prominent at the expense of parties, ideologies, and substantive political issues.

The growing importance of individuals in the political process has been put under scrutiny under multiple perspectives by political scientists. Previous research on the topic can nonetheless be summarized into three major categories, dealing in turn with political institutions (i.e., parties and electoral systems), political communication, and citizens' voting behavior (Karvonen, 2010).
Available research shows that over the last three decades there has been a marked shift toward more personalized electoral systems (Renwick \& Pilet, 2016). Institutional analyses have also stressed the growing importance of leaders within their own parties (Poguntke \& Webb, 2005). The increasing centrality of political leaders in contemporary postbureaucratic parties has been shown to bear strong effects on patterns of political and electoral competition in turn. Previous research provides evidence that the transformation undergone by political parties in the last decades has fostered the role of individual leaders in driving voters' feelings of closeness to the party and, eventually, their voting behavior (Garzia, 2012, 2013a; Lobo, 2008). Also political communication research devoted a strong interest to the process of personalization. Analyses of modern election campaigns emphasized the increased visibility of political leaders at the expense of the respective parties (Kriesi, 2012; Mazzoleni \& Schulz, 1999; Swanson \& Mancini, 1996). Yet, not much is known about the relationship between changing patterns of political communication and the

CONTACT Diego Garzia diego.garzia@unilu.ch Department of Political Science, University of Lucerne, Frohburgstrasse 3, 6002 Lucerne, Switzerland. Previous versions of this article have been presented at the ITANES/SISE Workshop in memory of Aldo Di Virgilio (Bologna, February 2016), the WPSA Annual Meeting (San Diego, March 2016), the EUI Political Behavior Colloquium (Fiesole, April 2016), the ECPR General Conference (Prague, September 2016), the Internet, Policy and Politics Conference (Oxford, September 2016), the SPSA Annual Conference (St. Gallen, January 2017), the MPSA Annual Conference (Chicago, April 2017), as well as at the Jack W. Peltason Center for the Study of Democracy's Departmental Seminar (Irvine, April 2017). Amongst the large number of people that I would like to thank for their support, useful comments and suggestions throughout the last two years, I will single out Paolo Bellucci, Neil Bendle, Daniel Bochsler, Russell Dalton, Andrea De Angelis, Catherine Dong, Marta Fraile, Carol Galais, Bernie Grofman, Sharon Haleva-Amir, Enrique Hernandez, Jeff Kopstein, Hanspeter Kriesi, Elie Michel, Davide Morisi, Anand Shastri (best discussant ever), Frederico Ferreira da Silva, Tiago Silva, Alex Trechsel, Stefaan Walgrave and Marty Wattenberg. Needless to say, all the unavoidable mistakes still present remain only mine.

(c) 2017 Taylor \& Francis 
electoral effect of party leader evaluations at the individual level. In particular, the role played by television as a vehicle of personalization in voting behavior, as well as the relationship between online-based political communication and the personalization trend have been by and large neglected by the previous scholarship on the topic.

This paper aims at filling these gaps through a case study of the Italian parliamentary election of February 2013. As a matter of fact, Italy provides an ideal case for the study of the personalization of politics and its relationship with political communication (Campus, 2010). Initially unfolded in the early 1990 s as a result of party system breakdown and the simultaneous "entrance in the field" of media tycoon Silvio Berlusconi, personalization has heavily characterized the last two decades of Italian politics. In spite of their pivotal role in both party structures (Calise, 2000) and political communication (Mazzoleni, 1996), only a few studies investigated systematically the impact of party leaders on Italians' electoral behavior (Bellucci, Garzia, \& Lewis-Beck, 2015; Garzia, 2013b; Venturino, 2000). A previous longitudinal study found relatively strong evidence of the link between the progressive personalization of party structures and increasing leader effects on voting behavior (Garzia \& Viotti, 2011). In contrast, the relationship between media change and personalization in voting behavior has never been systematically measured. Within this context, the 2013 election stands as a potentially crucial point. Eventually, the historical dominance of television as the main source of political information for the electorate at large is counterbalanced by the emergence of the Internet (Bentivegna and Ceccarini, 2013). This development is paralleled by the massive instant success of Beppe Grillo's Internet-based Five Star Movement at the expense of "traditional" parties. The extent to which these two phenomena relate to each other, however, is currently a matter of debate (Barisione, Catellani, \& Garzia, 2014). By looking at the electoral effect of political leaders across different audiences, this paper elaborates on what has been the missing link in electoral research on party leader effects, while also speaking to the broader question of how important the media is for the outcome of contemporary democratic elections.

The paper is structured as follows. The next section reviews the few available works from the international literature dealing with the connection between exposure to old and new media and leader effects on voting. The following sections present the case study, the data set and the operational measures in turn. The analysis investigates the importance of leaders in the voting calculus across voters' varying degrees of television exposure and political activity on the Internet. The results, showing the dominance of leader effects among voters strongly exposed to television and a somewhat differentiated impact on Internauts, are tested for their robustness across a wide range of model specifications and alternative operationalizations of dependent and independent variables. The final section discusses the major implications of the findings and concludes with an agenda for future research in the field.

\section{Personalization of politics between television and the Internet}

There is no doubt that the changing structure of mass communications in the second half of the 20th century has been central in emphasizing the role of political leaders at the expense of parties, making the latter "more dependent in their communications with voters on the essentially visual and personality-based medium of television" (Mughan, 2000, p. 129). The link between television and the personalization of politics has been repeatedly put forward (Druckman, 2003; Lenz \& Lawson, 2011; Postman, 2006; Sartori, 1989). Because of its power to present images, it is easier for television to communicate political information through "individual" objects rather than abstract entities such as parties or ideologies (Hayes, 2009). By calling attention to some features of political competition while ignoring others, television news influences "the standards by which governments, presidents, and candidates for public office are judged" (Iyengar \& Kinder, 1987, p. 63). News attention does not only affect the way in which candidates and leading politicians are judged. As a matter of fact, it also increases their perceived importance (Miller \& Krosnick, 2000). In this sense, the inner logic of televised political communication-along with the rise of the medium itself as the chief source of political information for the predominant majority of citizens -has been "blamed" for the growing relevance of personality evaluations in voters' choice over the last 
decades. Yet, the link between patterns of televised political information and the determinants of voting behavior has received only limited attention in the empirical literature so far.

Currently available research in this domain pertains mostly to the American case. McLeod, Glynn, and McDonald (1983) analyzed post-election survey data from the 1980 U.S. presidential election, and found that voters heavily exposed to television were the most likely to rely on candidate image characteristics while casting their vote. Keeter's (1987) longitudinal analysis of the period 1952-1980 supports McLeod et al.'s findings, concluding that "television has facilitated and encouraged vote choices based upon the personal qualities of candidates" (Keeter, 1987, p. 344). Similar findings are reported by Holian and Prysby (2014) in their recent analysis of candidate character traits in U.S. presidential elections.

Unlike their American counterparts, European scholars have only recently started addressing these issues. Among the few available works on the topic, Mughan's (2000) study of British elections stands as the first systematic contribution, and it supports the idea that higher degrees of exposure to televised political information correspond to an increasing influence of party leader evaluations on vote choice. These conclusions, however, are only partially supported by Rico's (2014) analysis of three Spanish elections and Elmelund-Præstekær and Hopmann's (2012) study of Danish local elections. More convincing evidence in support of the link between television and personalization is offered by Takens, Kleinnijenhuis, van Hoof, and van Atteveldt (2015) in their analysis of the 2010 Dutch parliamentary election. ${ }^{1}$

In line with the aforementioned literature, the first research question tackled in this paper can be formulated as follows: Is personality-based voting fostered by heavy exposure to television?

As it currently stands, the extant literature on the personalization of politics seems to have overlooked the momentous transformations that occurred on the media landscape due to the advent of the Internet. Notwithstanding the dramatic changes in the way in which online political information is produced and digested by the electorate (Sudulich, Wall, \& Baccini, 2015) there is only scattered evidence about the relationship between
Internet usage and the determinants of electoral choice. At first, the growth of the Internet and social media has sparked interest in its impact on increasing political engagement and participation, either directly, for example, encouraging them to participate, or indirectly, for example, providing citizens with the necessary information to participate (Norris, 2000). Indeed, consumption of political information on the Internet has been shown to bear a positive impact on broadly defined patterns of political engagement (for a review, see Boulianne, 2009) as well as more specific patterns of electoral participation (Bond et al., 2012; Tolbert \& McNeal, 2003).

When it comes to the relationship between exposure to political information on the Internet and individual-level patterns of voting behavior, the scant available literature fails to carry unequivocal indications. On the one hand, one notes that the interactive possibilities offered by Web 2.0 (and, most notably, by social media) now allow voters to "follow" politicians' activities on a daily basis. In a similar fashion, politicians themselves have now the possibility to bypass the role of parties as political intermediaries through social media channels. On the other hand, however, it has been shown that "online election news seekers are ... more likely to look to policy issues to determine their vote choice" (Gibson \& McAllister, 2006, p. 256). What matters the most, for the purposes of this study, is that their higher propensity to vote based on issues is paralleled by a weakening impact of personality evaluation in the voting calculus. Holian and Prysby (2014) analyze the link between consumption of political information on the Internet and the attitudinal determinants of vote choice based on national election study data from the 2012 U.S. presidential election. Their results support the idea that online news seekers are systematically less likely to base their candidate choice on personality evaluations as compared to television viewers.

So far, European scholarship on the topic has concentrated on individual's exposure to specific informational sources, with a growing interest in so-called Voting Advice Applications (VAAs). The existing literature supports the notions that VAAs foster turnout (Garzia, De Angelis, \& Pianzola, 2014; Gemenis \& Rosema, 2014) and "prime" 
issues at the expense of personality evaluations in the individual voting calculus (Walgrave, Van Aelst, \& Nuytemans, 2008). Besides this emerging strand of scholarship, however, the European case highlights the virtual absence of systematic studies connecting voters' exposure to Internet-based political information and leader effects on voting.

Due to the lack of systematic empirical evidence on the topic, the second research question that this paper will tackle is inevitably exploratory in character, and it unfolds as follows: How does Internetbased political information impact the role of personality evaluations in voting behavior?

\section{The 2013 Italian parliamentary election}

Italy represents a crucial case for the mediatization of politics and its links with the processes of party transformation and electoral change. In this respect, the collapse of the old partitocrazia in the early 1990s stands as a key point of departure for the wide-ranging political developments that unfolded throughout the last two decades. The disappearance of virtually all the parties that populated Italian politics since the end of WW2 produced the most appropriate conditions for new competitors to enter the field. In 1994, media tycoon Silvio Berlusconi established his own personal party, Forza Italia. His entrance in the political arena prompted to a large extent the process of personalization of Italian politics (Campus \& Pasquino, 2006). As a man who personally owned a media empire, and being himself highly adept in the language of television, Berlusconi would soon set a standard for personal campaigning with no comparable precedents in modern mass democracies (Calise, 2005). Indeed, the unforeseeable triumph of Forza Italia in the 1994 election made the other parties increasingly dependent on television, for it immediately seemed clear that "no party could remain in the contest without heavy use of mass communication channels" (Mazzoleni, 1996, p. 200). This process of transformation found its climax during the 2008 campaign, when the political supply reached unparalleled levels of personalization due to the choice of the main center-left party, Partito Democratico, to center its electoral strategy on the figure of its leader and prime-ministerial candidate, Walter Veltroni (Barisione, Catellani, \& Garzia, 2013).

This party-led development unfolded in parallel with the progressive expansion of television as the main source of political information for the Italian electorate. Whereas in 1990 "only" two thirds of the electorate resorted primarily to television for political information, in less than 20 years this proportion went up to reaching almost four voters out of five (see Figure 1). Notwithstanding the inherent limitations of a cross-sectional case study when it comes to long-term processes such as the personalization of politics, there are good reasons to believe that the 2013 Italian election provides a number of ideal conditions for the study of the determinants of voting behavior in a changing media environment: (a) because it corresponds to the first instance of decline of television (i.e., minus 7\% between 2008 and 2013) and (b) most important to the purposes

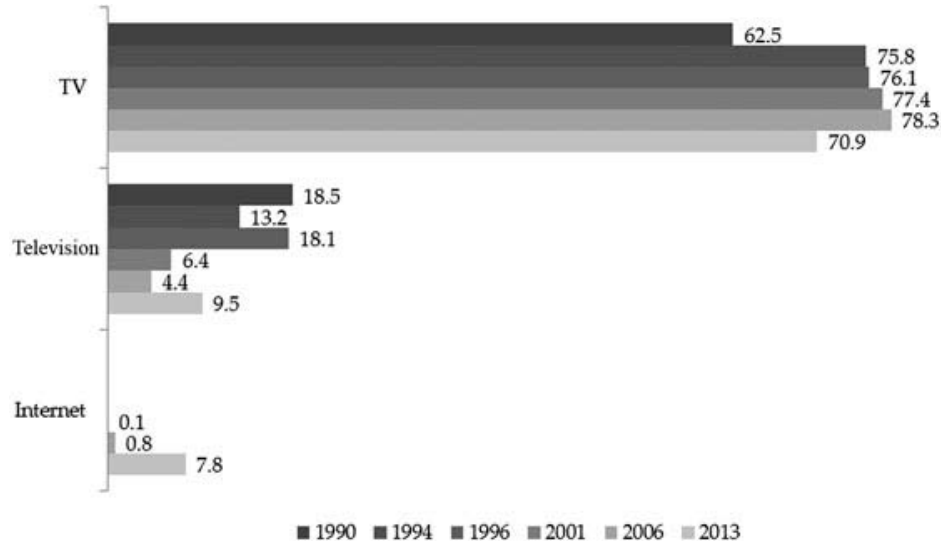

Figure 1. Italian voters' main source of political information (1990-2013).

Source: ITANES Series (1990-2013) 
of this paper, because television's decline is paralleled by the entrance of the Internet into the game -now representing the major source of political information to almost $8 \%$ of eligible voters (the figure being $10 \%$ across those who did actually cast a vote).

The aforementioned changes in patterns of media consumption relate in fascinating ways to the outcome of an election that witnessed the massive decline of traditional parties at the advantage of a brand-new (and by then almost entirely Internetbased) political movement. Albeit with a much smaller margin than forecast, the winning coalition was the center-left led by Pier Luigi Bersani, with $29.6 \%$ of the valid votes, while Berlusconi's centerright coalition gained $29.2 \%$ of the votes. In other words, the two "traditional" coalitions obtained less than $60 \%$ of the valid votes together (as compared to $84 \%$ in 2008 and $99 \%$ in 2006). The biggest surprise was Beppe Grillo's Movimento 5 Stelle (Five Star Movement) with $25.6 \%$ of the votes, which made it the third political force in the country as well as the most electorally successful newcomer of Italian political history (Biorcio, 2013). Although an analysis of the organizational features of Grillo's movement lies beyond the scope of this article, it is worth remembering that-unlike its traditional counterparts-the Five Star Movement originates as a by-product of Grillo's personal blog and still relies to a large extent on the Web as its key organizational resource (for an extensive discussion, see Bordignon \& Ceccarini, 2013).

\section{Data and measures}

The empirical analysis that follows will rely on the 2013 Italian National Election Study (ITANES) postelectoral data set. This is a nationally representative multistage sample conducted through face-to-face interviews/CAPI. ${ }^{2}$ The dependent variable of the analysis is vote choice. Due to the central position granted to electoral coalitions by the current Italian electoral law, the analysis will focus on coalition rather than party choice throughout the analysis. In the light of the election results, which saw the three major coalitions awarded more than $80 \%$ of the popular vote, I will model voting as a fourfold choice between Bersani's center-left coalition, Berlusconi's center- right coalition, Grillo's Five Star Movement, and minor parties/coalitions. ${ }^{3}$

When it comes to measuring respondents' media exposure, the available literature has suggested numerous possibilities, each of which carries methodological advantages as well as substantive drawbacks. Apparently, the most straightforward way to measure respondents' exposure to televised political information in the context of a survey would consist of asking them to self-assess the amount of time spent watching the news. However, Prior (2009) compared survey estimates with Nielsen estimates, and found severe overreporting of news exposure on behalf of survey respondents. According to Prior, error occurs at the estimation stage rather than as a product of social desirability bias. Against this background, he thus proposes to concentrate on the exposure to message reception, ideally through political knowledge indicators (see also Price \& Zaller, 1993). As he admits, however, this approach "does not help us study the effect of exposure" (Prior, 2009, p. 139). Moreover, political knowledge indicators are much less common in traditional election study data sets compared to media exposure indicators. For instance, the comparative analysis by Gidengil (2011) resorts-by necessity-to mere television exposure insofar as it represents the only comparable measure available in her cross-national election study data set.

Although suboptimal, mere television exposure can be thought to approximate actual information exposure because (a) we know that news watching increases proportionally to television watching (Wonneberger, Schoenbach, \& van Meurs, 2011) and (b) a measure of mere television exposure is also able to subsume, to at least some extent, the amount of information gathered as a result of accidental exposure. According to passive learning theories, the simple availability of information produces learning (Zukin \& Snyder, 1984). In this sense, "even broadcast viewers who prefer entertainment programs absorb at least basic political knowledge when they happen to tune in when only news is on" (Prior, 2005, p. 579).

In light of all the aforementioned considerations, I will segment ITANES respondents on the basis of their self-reported amount of television hours per day. To better understand the pervasiveness of television in Italian households during the 
2013 election, it suffices to say that only 5\% of respondents in the sample declare to have watched less than 30 minutes of television per day. The median respondent watched between two and three hours, while over a quarter of the sample watched between three and six hours.

As no comparable measure for Internet usage is available in the ITANES data set, the analysis will resort to the battery on political activity on the Internet, ranging from lighter forms of activity such as watching video content to more substantive ones such as attending (in person) political events that have been organized online (see full list in Table 1). The data presented in the table provides some interesting patterns. First of all, it is interesting to observe that, among all possible political activities on the Web, voters resorted mostly to "watching video content"-that is, typically, old media content online. Second, and somehow surprisingly given the relatively lenient selection of items in the battery, the proportion of respondents having performed at least one of these activities online does not rise much above one quarter.

Table 2 presents the cross tabulation of these two variables, with columns partitioning respondents by levels of daily exposure to television (low $=$ less than three hours per day; high $=$ three or more hours per day) and rows partitioning them by patterns of political activity on the Internet (yes = performed at least one of the activities in the battery; no = did not perform any online political activity). ${ }^{4}$ This coding scheme has the advantage of isolating in an almost perfect way the two audiences of interest, with $25 \%$ of respondents reporting heavy exposure to television and no political activity on the Internet, $23 \%$ with comparatively lower exposure to television but politically active on the Internet, and only a negligible proportion (around 4\%) of respondents heavily exposed to television and politically active on the Internet at the same time.

Table 1. Patterns of Political Activity on the Internet.

\begin{tabular}{lc}
\hline & $\%$ \\
\hline Watched video content about the campaign & 17.7 \\
Visited political Web site & 16.2 \\
Visited political social network profile & 14.2 \\
Shared content about the campaign & 12.2 \\
Participated in online political discussions & 8.6 \\
Participated in an event organized online & 6.2 \\
Performed (at least) one of the above & 28.7 \\
\hline
\end{tabular}

Table 2. Television Exposure and Patterns of Political Activity on the Internet.

\begin{tabular}{lccc}
\hline Web & & & \\
\hline No & Low & High & Total \\
$(N)$ & $47.9 \%$ & $23.4 \%$ & $71.3 \%$ \\
Yes & $(722)$ & $(353)$ & $(1,075)$ \\
$(N)$ & $24.9 \%$ & $3.8 \%$ & $28.7 \%$ \\
Total & $(375)$ & $(58)$ & $(433)$ \\
$(N)$ & $72.8 \%$ & $27.2 \%$ & $100 \%$ \\
& $(1,097)$ & $(411)$ & $(1,508)$ \\
\hline
\end{tabular}

Moving to the measurement of voters' evaluation of leaders, the analysis will rely on politically relevant personality traits. ${ }^{5}$ A wide body of available works supports the idea that the traits used to evaluate politicians are limited in number and tend to load onto a few general categories (Bittner, 2011). The ITANES series conforms to the closeended trait battery developed in 1980 by the American National Election Study (Kinder, Abelson, \& Fiske, 1979). Respondents are thus asked whether they perceive each of the major coalition's leader to be competent, honest, empathic, and a strong leader. According to the data presented in Table 3, the respective coalitions' leaders differ sharply in terms of perceived personality characteristics. Especially noteworthy are the rather low values relative to Berlusconi's honesty (only 19\% of respondents consider him a honest politician), Bersani's leadership strength (36\%), and Grillo's competence $(40 \%)$. In order to assess the overall impact of leaders' personality on respondents' electoral calculus, their evaluation of coalition leaders will be measured through an additive personality trait index ranging, for each individual respondent, from " 0 " (leader is credited with no single characteristic) to " 1 " (leader is credited with all four characteristics). ${ }^{6}$ Mean values of the additive personality trait index show that both Bersani and Grillo enjoy a substantial advantage vis-à-vis the long-term center-right leader Berlusconi.

If broken down by respondents' patterns of media consumption, mean values of the index provide a few key findings. Although respondents' evaluation of center-left leader Bersani does not seem to differ across levels of television consumption and patterns of political activity on the Internet, both Berlusconi and Grillo appear to enjoy a strong competitive advantage across heavy television viewers and political Internauts, respectively. 
Table 3. Leaders' Personality Traits and Overall Score on the Additive Personality Trait Index.

\begin{tabular}{lccc}
\hline & $\begin{array}{c}\text { Bersani } \\
\text { Center-left } \\
\text { coalition }\end{array}$ & $\begin{array}{c}\text { Berlusconi } \\
\text { Center-right } \\
\text { coalition }\end{array}$ & $\begin{array}{c}\text { Grillo } \\
\text { Five Star } \\
\text { Movement }\end{array}$ \\
\hline Leadership & .36 & .81 & .68 \\
Competence & .73 & .61 & .40 \\
Honesty & .68 & .19 & .61 \\
Empathy & .58 & .39 & .68 \\
$\begin{array}{l}\text { Additive personality trait index } \\
\text { All respondents }\end{array}$ & .59 & .49 & .59 \\
$\begin{array}{l}\text { By level of TV } \\
\text { consumption }\end{array}$ & & & \\
$\quad$ Low & .59 & $.47^{*}$ & .60 \\
$\quad$ High & .59 & $.56^{*}$ & .56 \\
By political activity on & & & \\
$\quad$ the Web & & & \\
$\quad \begin{array}{l}\text { Politically inactive } \\
\text { Politically active }\end{array}$ & .58 & .50 & $.54^{*}$ \\
\hline
\end{tabular}

Note. Asterisks signal that the $t$ test of paired means is significant at the .001 level (two-tailed).

\section{Analysis}

In order to assess the impact of voters' evaluation of party leaders' personality on their patterns of vote choice, I make use of logistic regression. Modeling strategy and the comprehensive set of covariates included in the analysis rely on the valence politics literature (Clarke et al., 2004). The composite modeling strategy relates to the different assumptions involved in modeling the choice to vote for incumbent and opposition parties, respectively. Insofar as voting for the incumbent party vis-à-vis any of its opposition rivals can be considered a fundamental electoral decision of its own, the first column of Table 4 reports the results of a binomial logistic regression, which pits center-left voting versus voting for any of the other coalitions. The second and third columns report the results of a multinomial logistic regression, which provide more detailed information about the factors driving voters to cast a ballot for opposition parties (in this case, center-left voting is used as the reference category). Controls include respondents' long-term ideological orientations (measured though self-placement on the leftright scale), their retrospective assessment of the state of the economy in the country, and whether the coalition voted for is considered the best at solving the most important issue in the country, plus controls (i.e., region of residence and frequency of church attendance). Age, gender, and educational level are also included, in order to control for sociodemographic differences between heavy television viewers and political Internauts (descriptive statistics for all independent variables included in the analysis are presented in Appendix B).

Table 4 provides a detailed report of the performance of the various variables in predicting a vote for each of the main coalitions. As all table entries are measured on a 1-point scale, coefficients are comparable in magnitude. The results clearly highlight the dominance of the leader's evaluations as driver of his respective coalition choice.

The dominance of coalition leaders as drivers of vote choice in the 2013 election is further highlighted in Figure 2, where the estimated effect of leader evaluations is summarized by means of the predicted probability of casting a vote for a given coalition moving from the minimum to the maximum value of the predictor of interest (with all other variables included in the model set at their mean value). The effect of leader evaluations appears relatively stronger for the Five Star Movement, with voters crediting Beppe Grilo with the highest score on the trait index, being $59 \%$ more likely to vote for his party compared to those assigning him the lowest score on the trait index. Lower figures can be credited to Bersani (49\% increase in predicted probability to vote for the center-left coalition moving from a completely negative to a completely positive evaluation of its leader) and Berlusconi (32\% increase). The importance of leader evaluations emerges even more clearly by comparing them with the explanatory power of the second-best predictor included in the model, that is, perceived competence at the most important issue. Although the latter is only slightly less important in the case of the Five Star Movement, it is worth noting that competence is outnumbered by leader evaluations with ratios ranging between 2:1 (center-left coalition voting) and 4:1 (center-right coalition voting).

After having assessed the dominance of leaders in the respondents' voting calculus, the analysis now turns to answering the central questions of this paper, focusing on the relationship between leader effects and patterns of television exposure and political activity on the Internet in turn. To do so, I follow the analytical strategy employed by 
Table 4. The Determinants of Vote Choice in the Italian Election of 2013.

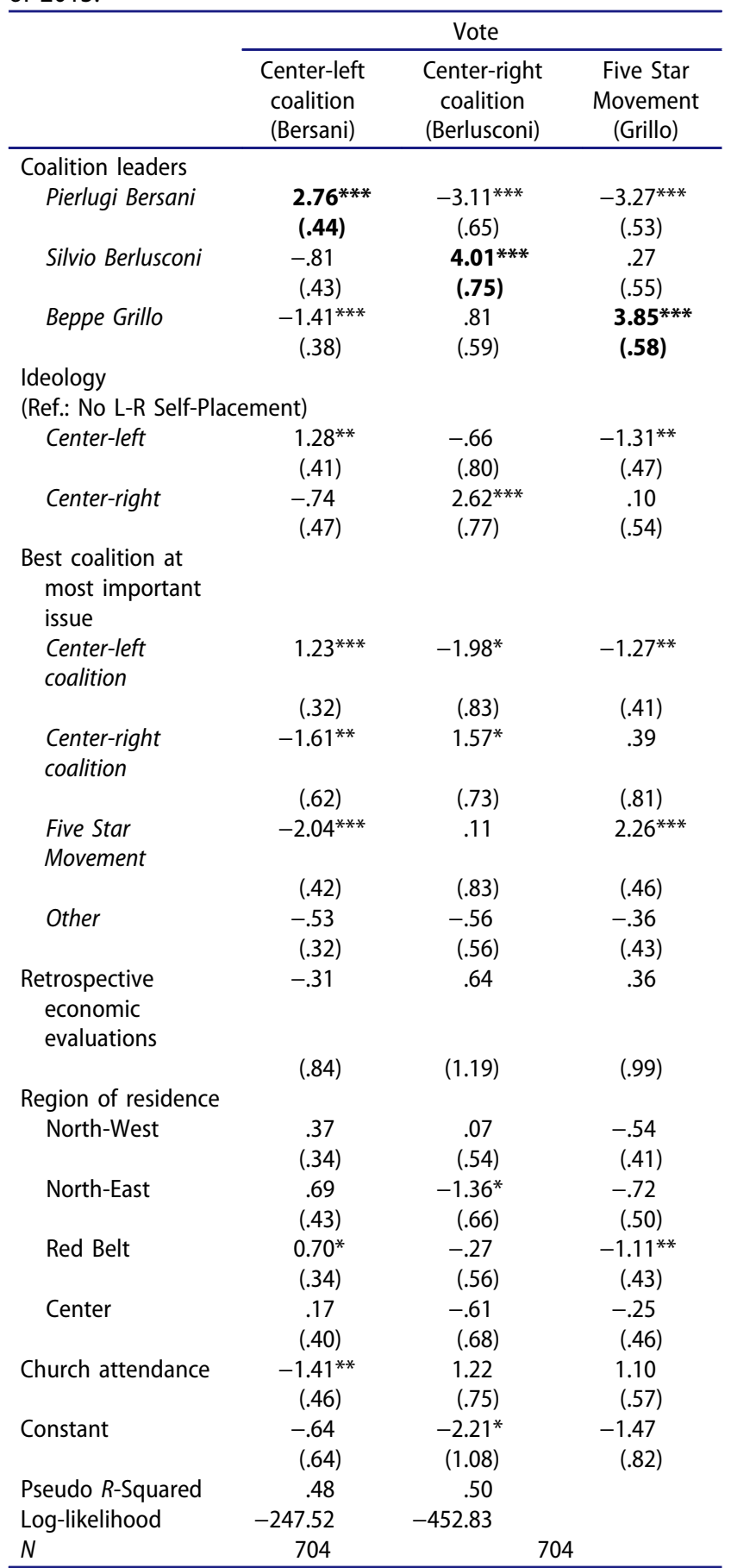

Notes. First column's coefficient are from a binomial logit (centre-left vs. all other coalition voting). Centre-right coalition and Five Star Movement analysis is a multinomial logit with centre-left coalition as the reference category. Other party voting is included in the multinomial logit analysis but coefficients are not displayed in table Age, gender and educational level are included in all models. Coefficients are not shown.

${ }^{* * *} p \leq .001 .{ }^{* *} p \leq .01 .{ }^{*} p \leq .05$.

Holian and Prysby (2014) in their analysis of leader effects by levels of media exposure. That is, I replicate the analysis presented in Table 4 on split samples (i.e., low vs. high levels of television consumption, and politically inactive on the Internet $v s$. politically active on the Internet). As logistic coefficients from split-sample estimations are not straightforwardly comparable in magnitude, I only report the changes in predicted probabilities of coalition voting moving from the minimum to the maximum value of each leaders' personality trait index while keeping all other variables in the model set at their means.

Findings from Figure 3 are strongly in line with expectations. The effect of coalition leader evaluations on voting is systematically stronger for those heavily exposed to television. This is especially the case for voters of Berlusconi's coalition, who appear to rely on their evaluation of the leader twice as much if heavily exposed to television as compared to those reporting comparatively lower patterns of television exposure. This finding comes by and large as no surprise, given the much higher popularity of Berlusconi across heavy TV viewers (see Table 3). Ratios of leader effects across television viewership groups are less spectacular in the cases of Grillo's movement as well as Bersani's coalition, but they witness nonetheless the stronger importance of leader evaluations for those voters more heavily exposed to television. ${ }^{7}$

Findings from the Internet analysis are presented in Figure 4. Politically active citizens voting for established parties would seem to pay less attention to leaders' personality within their voting calculus. This appears to be especially the case for voters of the center-right coalition. According to the results of the simulation stemming from the multinomial regression analysis, the coalition leader's evaluation turns even insignificant across the group of politically active on the Internet. Though this is not the case for center-left voters, one notes nonetheless that coalition leader Bersani matters roughly twice as much for those not active on the Internet. The most interesting finding of this analysis, however, comes from the case of Five Star Movement voters. Here, party leader Grillo would appear to matter more for those politically active on the Web.

Taken together, these findings suggest an interesting interpretation by which leader effects do not depend on the main source of information per sé. Their magnitude would seem to rather interact with 


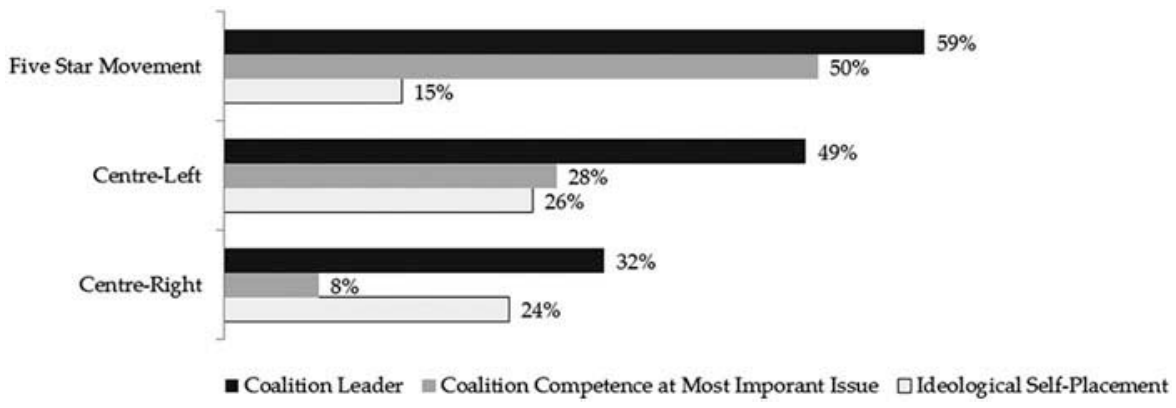

Figure 2. Predicted probability of coalition voting by key independent variables.

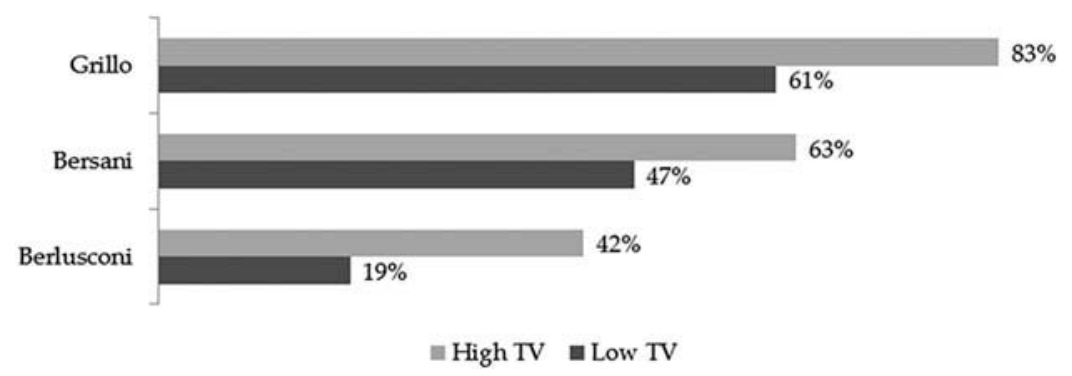

Figure 3. Predicted probability of coalition voting by evaluation of the respective leader and level of television exposure.

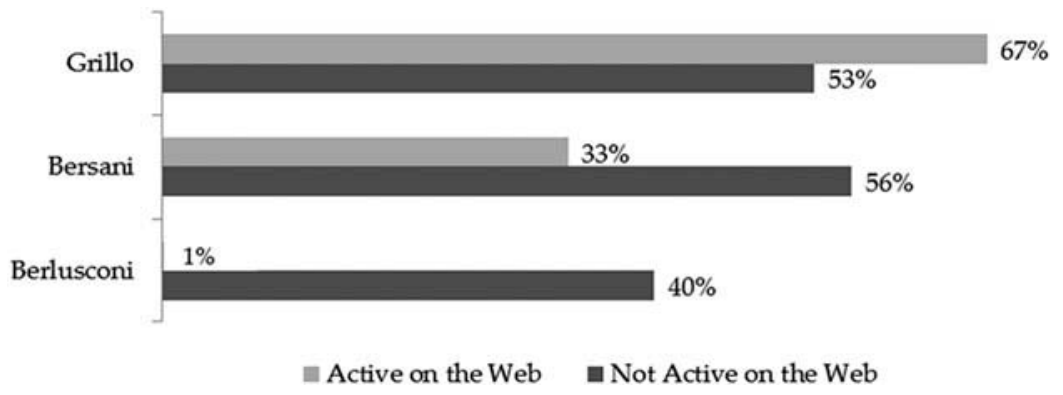

Figure 4. Predicted probability of coalition voting by evaluation of the respective leader and political activity on the Internet.

the characteristics of the political offer and their respective interaction with old as well as new media. Leaders of more traditional political formations that rely mostly on television for political communication matter more to those voters heavily exposed to television. In turn, their lack of appeal to political Internauts might explain their smaller importance within their voting calculus, and account in turn for the strong effect of Beppe Grillo on this segment of voters.

\section{Robustness}

To test the robustness of these findings to model specification and variable measurement, I performed extensive tests. First, I tested a different operationalization of the dependent variable with party votes in place of coalition votes (Table A.1 in Appendix A). Second, I tested a different measurement of coalition leaders' evaluation by replacing the additive personality trait index with leaders' thermometer scores (Table A.2). Third, I reran all models with a threefold segmentation of exposure to television (i.e., low, medium, and high exposure; Table A.3). Fourth, I tested the robustness of the results against different measurements of political activity on the Internet, by excluding one activity at a time from the index (Table A.4). ${ }^{8}$ In all but one instance, the results of the robustness tests confirmed those presented in Figures 3 and $4 .^{9}$ 


\section{Discussion and conclusions}

This paper looked into a key development of the democratic process - the personalization of politics. Whereas previous works tackled the role played by party change in driving the personalization of voting behavior across time, this contribution focused on the part played by individual exposure to political information on different types of media in conditioning leader effects on voting. The analysis of the determinants of vote choice in the 2013 Italian election confirms the notion that individuals' evaluation of political leaders' personality is a key variable in their voting equation. As to the relationship between leader effects on voting and media exposure, this paper contributes to the extant literature by supporting the idea that leader effects are somehow fostered by heavy exposure to television. Insofar as television is (at least partly) responsible for the heightened importance of party leader evaluations in the voting calculus, what is the intervening role of the Internet? The answer that can be derived from our empirical results is twofold, and it depends on the type of parties for which people cast their vote. Indeed, the leader would seem to matter less to Internauts voting for traditional parties but more to those of them voting for the (largely online-based) Five Star Movement. This intrinsically unsurprising conclusion hints nonetheless at a potential development of utmost political relevance. In a way similar to how Berlusconi gathered personal popularity and electoral influence through television, forcing all his political competitors to surrender to his media logic accordingly, Grillo might be paving the way for traditional parties and their respective leaders to "invade" the online arena. The political communication of former Italian Prime Minister Matteo Renzi has been proved to be a telling example in this respect (Bordignon, 2014). In turn, this supports a fascinating idea by which rather than depersonalizing politics, the Internet itself might provide parties and leaders with a new arena to actually foster patterns of political personalization.

In view of the rapid spread of the Internet as the most important (and at times only) source of political information for Western electorates, further research in this domain is in urgent need -also taking into account the wide range of formats through which political information is made available by the Internet. On the one hand, the Web has proven its capability of "bringing the written word back in" as all newspapers become available - free of charge - to every user (Morris, 1999). In a similar vein, personality-based dynamics that originate in television have found in the Web a fertile ground. According to the results presented in this analysis, most of the political activity on the Internet consists in watching video content. Although candidates and political leaders' video content is widely present-and increasingly so-on the Internet through social media and YouTube video channels (Gibson \& McAllister, 2011), YouTube itself has been shown to have turned from "an innovative source of news and political information to one more hospitable to mediated information produced by media corporations" (May, 2010, p. 501). At the same time, however, the interactive possibilities of social media have highlighted the possibility for voters to connect horizontally, thus reviving classic theories of social influence and interpersonal intermediation on vote choice (Miller, Bobkowski, Maliniak, \& Rapoport, 2015). ${ }^{10}$

The comparative assessment of-not necessarily - conflicting hypotheses will help move toward a systematic theory of Internet effects on voting behavior. As a point of departure, such a theory might find useful a twofold conceptualization of the Internet's informational features, pitting old media online (i.e., newspapers and television broadcasters) against new media online (e.g., social media) as a way to isolate their potentially different impacts on voting. The theoretical development will certainly benefit from a more comparative focus, with research also taking into account less peculiar party systems (for instance, where television is not by and large "owned" by one of the main political actors and the Internet is not "home" of the organizational structure of another) and contexts (for instance, countries where television is a less powerful source of political information and/or the Internet is a more powerful source). ${ }^{11}$

Finally, the results presented in this paper call for explicitly longitudinal analyses able to take into account the intervening role of party transformation in the process of progressive personalization of elections. Thirty years ago, Meyrowitz (1985) made clear 
the practical impossibility of assessing the impact of old (as well as new) media in isolation with all other (political) variables. Whereas previous works have documented the relationship between the "fourth information revolution" and the transformation of party organizations (Bimber, 2003; Mancini, 2015), the initial results presented here highlight the crucial need to integrate theories from both political communication and party research into a "shared research agenda" for future analyses of electoral change at the individual level.

\section{Notes}

1. So far, only one study by Gidengil (2011) tackled the issue in a comparative perspective-albeit with inconclusive results due to the acknowledged limitations within the available data.

2. From a methodological point of view, sticking to survey data alone implies opting (along the lines of virtually all existing research on the topic) for an "attentiveness" approach. This approach carries some drawbacks as compared to a "linkage" approach, most notably, the inability to connect the actual content of media coverage to individual patterns of voting behavior. However, the "linkage" approach comes with problems too. According to Dobrzynska et al. (2003, p. 29), the major limitation of this approach refers to the fact that it "does not address the bottom line question, that is, how much effect the media do exert on voters' final choice." Given the foremost interest of this paper in the very same bottom-line question, I thus decided to resort to the "attentiveness" approach, yet keeping in mind its inherent limitations when it comes to interpretation and generalization of the empirical findings.

3. Because the analysis deals with the determinants of vote choice, I will leave aside respondents who abstained as well as those who picked the 'did not vote,' 'do not know,' or 'no answer' response options. In turn, this lowers the number of cases included in the analysis down to $N=950$.

4. The choice to sum up all the items from the Internet activity battery into a single additive scale is supported by the results of a factor analysis (all items load heavily onto the same factor; Cronbach's Alpha for the additive index equals .84). I further tested different versions of the index by excluding one activity at a time, each time obtaining the very same results.

5. The use of personality traits in place of thermometer score evaluations relies on the idea set forth by Fiorina (1981) that the thermometer might also be capturing factors such as retrospective judgments, party influence, issue positions, and so on.
6. Respondents have been asked to rate each political leader on the four traits on a 4-point scale ranging from "not at all" to "very much." Each variable has then been rescaled: "0" stands for a negative attitude (i.e., "not at all" and "not very much") while " 1 " stands for a positive attitude (i.e., "fairly much" and "very much").

7. Previous contributions highlighted that Grillo's popularity, already high among Internauts, grew exponentially among television viewers throughout the 2013 campaign as a result of the progressive hybridization of the Italian media system (Barisione et al., 2014).

8. Unfortunately, it was not possible to estimate the effect of coalition leader evaluations on single-activity-based subgroups of Internauts due to the very low number of cases.

9. When testing the model on party rather than coalition choice, Berlusconi appeared somewhat less important to respondents heavily exposed to television.

10. Bentivegna and Ceccarini (2013) show that the figure for political discussion during the 2013 election campaign was $66 \%$ among citizens who used the Internet to get political information compared to $45 \%$ for all others.

11. It is worth highlighting that Italy ranks fourth in the world-and first among Western European countries -when it comes to average daily television viewing time per person (http://www.statista.com/statistics/ 276748/average-daily-tv-viewing-time-per-person-inselected-countries/ [last accessed: 07/16/2017]). At the same time, Italy also ranks way below the EU27 average with regard to the frequency of Internet use (http://ec.europa.eu/eurostat/statistics-explained/ index.php/File:Internet_use_and_frequency_of_use_ by_individuals,_2013_(\%25_of_individuals).png)

\section{Notes on contributor}

Diego Garzia is Senior Researcher and Lecturer in the Department of Political Science, University of Lucerne.

\section{References}

Barisione, M., Catellani, P., \& Garzia, D. (2013). Alla ricerca di un leader. In ITANES (Ed.), Voto amaro. Disincanto e crisi economica nelle elezioni del 2013. Bologna, Italy: Il Mulino pp. 147-157

Barisione, M., Catellani, P., \& Garzia, D. (2014). Tra Facebook ei TG. Esposizione mediale e percezione dei leader nella campagna elettorale italiana del 2013. Comunicazione Politica, 15(1), 187-210.

Bellucci, P., Garzia, D., \& Lewis-Beck, M. (2015). Issues and leaders as vote determinants. The case of Italy. Party Politics, 21(2), 272-283. doi:10.1177/1354068812472583

Bentivegna, S., \& Ceccarini, L. (2013). Web, giovani e voto. In ITANES (Ed.), Voto amaro. Disincanto e crisi economica nelle elezioni del 2013. Bologna, Italy: Il Mulino pp. 193204 
Bimber, B. (2003). Information and American democracy: Technology in the evolution of political power. Cambridge, England: Cambridge University Press.

Biorcio, R. (2013). La sfida del Movimento 5 stelle. In ITANES (Ed.), Voto amaro. Disincanto e crisi economica nelle elezioni del 2013. Bologna, Itlay: Il Mulino. pp. 107-119

Bittner, A. (2011). Platform or personality? The role of party leaders in elections. Oxford, England: Oxford University Press.

Bond, R., Fariss, C., Jones, J., Kramer, A., Marlow, C., Settle, J., \& Fowler, J. (2012). A 61-million-person experiment in social influence and political mobilization. Nature, 489, 295-298. doi:10.1038/nature11421

Bordignon, F. (2014). Matteo Renzi: A "Leftist Berlusconi" for the Italian Democratic Party? South European Society and Politics, 19(1), 1-23. doi:10.1080/ 13608746.2014 .887240

Bordignon, F., \& Ceccarini, L. (2013). Five stars and a cricket. Beppe Grillo shakes Italian politics. South European Society and Politics, 18(4), 427-449. doi:10.1080/ 13608746.2013.775720

Boulianne, S. (2009). Does Internet use affect engagement? A meta-analysis of research. Political Communication, 26(2), 193-211. doi:10.1080/10584600902854363

Calise, M. (2000). Il partito personale. Rome/Bari, Italy: Laterza.

Calise, M. (2005). Presidentialization: Italian style. In T. Poguntke \& P. Webb (Eds.), The presidentialization of politics: A comparative study of modern democracies. Oxford, England: Oxford University Press.

Campus, D. (2010). Mediatization and personalization of politics in Italy and France: The cases of Berlusconi and Sarkozy. The International Journal of Press/Politics, 15(2), 219-235. doi:10.1177/1940161209358762

Campus, D., \& Pasquino, G. (2006). Leadership in Italy: The changing role of leaders in elections and in government. Journal of Contemporary European Studies, 14(1), 25-40. doi:10.1080/14782800600617912

Clarke, H., Sanders, D., Stewart, M. and Whiteley, P., (2004). Political Choice in Britain. Oxford: Oxford University Press.

Dobrzynska, A., Blais, A., \& Nadeau, R. (2003). Do the media have a direct impact on the vote? The case of the 1997 Canadian election. International Journal of Public Opinion Research, 15(1), 27-43. doi:10.1093/ijpor/15.1.27

Druckman, J. (2003). The power of television images: The first Kennedy-Nixon debate revisited. Journal of Politics, 65 (2), 559-571. doi:10.1111/1468-2508.t01-1-00015

Elmelund-Præstekær, C., \& Hopmann, D. (2012). Does television personalise voting behaviour? Studying the effects of media exposure on voting for candidates or parties. Scandinavian Political Studies, 35(2), 117-140. doi:10.1111/scps.2012.35.issue-2

Fiorina, M. (1981). Retrospective voting in American national elections. New Haven: Yale University Press.

Garzia, D. (2012). Party and leader effects in parliamentary elections: Towards a reassessment. Politics, 32(3), 175-185. doi:10.1111/j.1467-9256.2012.01443.x
Garzia, D. (2013a). The rise of party/leader identification in Western Europe. Political Research Quarterly, 66(3), 533544. doi:10.1177/1065912912463122

Garzia, D. (2013b). Can candidates' image win elections? A counterfactual assessment of leader effects in the second Italian Republic. Journal of Political Marketing, 12(4), 348361. doi:10.1080/15377857.2013.837303

Garzia, D., De Angelis, A., \& Pianzola, J. (2014). The impact of VAAs on electoral participation. In D. Garzia \& S. Marschall (Eds.), Matching voters with parties and candidates. Colchester, England: ECPR Press. pp. 105-114

Garzia, D., \& Viotti, F. (2011). Leader, identità di partito e voto in Italia, 1990-2008. Rivista Italiana Di Scienza Politica, 41(3), 411-432.

Gemenis, K., \& Rosema, M. (2014). Voting advice applications and electoral turnout. Electoral Studies, 36, 281-289. doi:10.1016/j.electstud.2014.06.010

Gibson, R., \& McAllister, I. (2006). Does cyber-campaigning win votes? Online communication in the 2004 Australian election. Journal of Elections, Public Opinion and Parties, 16(3), 243-263. doi:10.1080/13689880600950527

Gibson, R., \& McAllister, I. (2011). Do online election campaigns win votes? The 2007 Australian "YouTube" election. Political Communication, 28(2), 227-244. doi:10.1080/10584609.2011.568042

Gidengil, E. (2011). Voter characteristics and leader effects. In K. Aarts, A. Blais, \& H. Schmitt (Eds.), Political leaders and democratic elections. Oxford, England: Oxford University Press.

Hayes, D. (2009). Has television personalized voting behavior? Political Behavior, 31(2), 231-260. doi:10.1007/ s11109-008-9070-0

Holian, D., \& Prysby, C. (2014). Candidate character traits in presidential elections. Abingdon, England: Routledge.

Iyengar, S., \& Kinder, D. (1987). News that matters. Television and American opinion. Chicago, IL: University of Chicago Press.

Karvonen, L. (2010). The personalisation of politics. A study of parliamentary democracies. Colchester, England: ECPR Press.

Keeter, S. (1987). The illusion of intimacy: Television and the role of candidate personal qualities in voter choice. Public Opinion Quarterly, 51(3), 344-358. doi:10.1086/269040

Kinder, D., Abelson, R., \& Fiske, S. (1979). Developmental research on candidate instrumentation: Results and recommendations. Report submitted to the Institute for Social Research, University of Michigan.

Kriesi, H. (2012). Personalization of national election campaigns. Party Politics, 18(6), 825-844. doi:10.1177/ 1354068810389643

Lenz, G., \& Lawson, C. (2011). Looking the part: Television leads less informed citizens to vote based on candidates' appearance. American Journal of Political Science, 55(3), 574-589. doi:10.1111/ajps.2011.55.issue-3

Lobo, M. (2008). Parties and leader effects: Impact of leaders in the vote for different types of parties. Party Politics, 14 (3), 281-298. doi:10.1177/1354068807088123 
Mancini, P. (2015). Il Post-Partito. Bologna, Italy: Il Mulino.

May, A. (2010). Who tube? How YouTube's news and politics space is going mainstream. The International Journal of Press/Politics, 15(4), 499-511. doi:10.1177/ 1940161210382861

Mazzoleni, G. (1996). Patterns and effects of recent change in electoral campaigning in Italy. In D. Swanson \& P. Mancini (Eds.), Politics, media and modern democracy. An international study of innovations in electoral campaigning and their consequences. Westport, CT: Praeger. pp. 193-206

Mazzoleni, G., \& Schulz, W. (1999). "Mediatization” of politics: A challenge for democracy? Political Communication, 16(3), 247-261. doi:10.1080/105846099198613

McAllister, I. (2007). The personalization of politics. In R. Dalton \& H.-D. Klingemann (Eds.), The Oxford handbook of political behaviour. Oxford, England: Oxford University Press. pp. 88106

McLeod, J., Glynn, C., \& McDonald, D. (1983). Issues and images: The influence of media reliance in voting decisions. Communication Research, 10(1), 37-58. doi:10.1177/ 009365083010001002

Meyrowitz, J. (1985). No sense of place: The impact of electronic media on social behavior. Oxford, England: Oxford University Press.

Miller, J., \& Krosnick, J. (2000). News media impact on the ingredients of presidential evaluations: Politically knowledgeable citizens are guided by a trusted source. American Journal of Political Science, 44(2), 301-315. doi:10.2307/2669312

Miller, P., Bobkowski, P., Maliniak, D., \& Rapoport, R. (2015). Talking politics on Facebook: Network centrality and political discussion practices in social media. Political Research Quarterly. Advance online publication. doi:10.1177/1065912915580135

Morris, D. (1999). Vote.com: How big-money lobbyists and the media are losing their influence, and the Internet is giving power to the people. Los Angeles, CA: Renaissance Books.

Mughan, A. (2000). Media and the presidentialization of parliamentary elections. Basingstoke, England: Palgrave Macmillan.

Norris, P. (2000). A virtuous circle. Political communication in post-industrial societies. Cambridge, England: Cambridge University Press.

Poguntke, T., \& Webb, P. (Eds.). (2005). The presidentialization of politics. A comparative study of modern democracies. Oxford, England: Oxford University Press.

Postman, N. (2006). Amusing ourselves to death: Public discourse in the age of show business. London: Penguin.

Price, V., \& Zaller, J. (1993). Who gets the news? Alternative measures of news reception and their implications for research. Public Opinion Quarterly, 57(2), 133-164. doi:10.1086/269363
Prior, M. (2005). News vs. entertainment: How increasing media choice widens gaps in political knowledge and turnout. American Journal of Political Science, 49(3), 577-592. doi:10.1111/ajps.2005.49.issue-3

Prior, M. (2009). The immensely inflated news audience: Assessing bias in self-reported news exposure. Public Opinion Quarterly, 73(1), 130-143. doi:10.1093/poq/ nfp002

Rahat, G., \& Sheafer, T. (2007). The personalization(s) of politics: Israel, 1949-2003. Political Communication, 24 (1), 65-80. doi:10.1080/10584600601128739

Renwick, A., \& Pilet, J.-B. (2016). Faces on the ballot: The personalization of electoral systems in Europe. Oxford, England: Oxford University Press.

Rico, G. (2014). Political sophistication and media consumption as factors of personalization. In M. Lobo \& J. Curtice (Eds.), Personality politics? The role of leader evaluations in democratic elections. Oxford, England: Oxford University Press.

Sartori, G. (1989). Video-power. Government and Opposition, 24(1), 39-53. doi:10.1111/j.1477-7053.1989.tb00106.x

Sudulich, L., Wall, M., \& Baccini, L. (2015). Wired voters: The effects of Internet use on voters' electoral uncertainty. British Journal of Political Science, 45(4), 853-881.

Swanson, D., \& Mancini, P. (Eds.). (1996). Politics, media, and modern democracy. An international study of innovations in electoral campaigning and their consequences. Westport, CT: Praeger.

Takens, J., Kleinnijenhuis, J., Van Hoof, A., \& Van Atteveldt, W. (2015). Party leaders in the media and voting behaviour. Priming rather than learning or projection. Political Communication, 32, 249-267. doi:10.1080/ 10584609.2014.944319

Tolbert, C., \& McNeal, R. (2003). Unraveling the effects of the Internet on political participation? Political Research Quarterly, 56(2), 175-185. doi:10.1177/ 106591290305600206

Venturino, F. (2000). La personalizzazione della politica italiana. Il ruolo dei leader nelle elezioni del 1996. Rivista Italiana Di Scienza Politica, 20(2), 295-328.

Walgrave, S., Van Aelst, P., \& Nuytemans, M. (2008). "Do the vote test": The electoral effects of a popular vote advice application at the 2004 Belgian elections. Acta Politica, 43 (1), 50-70. doi:10.1057/palgrave.ap.5500209

Wonneberger, A., Schoenbach, K., \& Van Meurs, L. (2011). Interest in news and politics-Or situational determinants? Why people watch the news. Journal of Broadcasting \& Electronic Media, 55(3), 325-343. doi:10.1080/ 08838151.2011 .597466

Zukin, C., \& Snyder, R. (1984). Passive learning: When the media environment is the message. Public Opinion Quarterly, 48(3), 629-638. doi:10.1086/268864 


\section{Appendix A. Detailed estimation procedure for robustness tests}

Table A.1. Different Operationalization of the Dependent Variable (Party Rather Than Coalition Votes).

\begin{tabular}{lccc}
\hline & $\begin{array}{c}\text { Partito } \\
\text { Democratico } \\
\text { (PD) }\end{array}$ & $\begin{array}{c}\text { Popolo } \\
\text { delle } \\
\text { Libertá } \\
(\mathrm{PdL})\end{array}$ & $\begin{array}{c}\text { Five Star } \\
\text { Movement }\end{array}$ \\
\hline $\begin{array}{l}\text { Level of TV exposure } \\
\text { Low }\end{array}$ & $36 \%$ & $16 \%$ & $55 \%$ \\
High & $46 \%$ & $7 \%$ & $84 \%$ \\
$\begin{array}{l}\text { Politically active on the Web } \\
\text { Low } \\
\text { High }\end{array}$ & $46 \%$ & $36 \%$ & $48 \%$ \\
\hline
\end{tabular}

Table A.2. Different Operationalization of Leader Evaluations (Thermometer Rather Than Trait Index).

\begin{tabular}{lccc}
\hline & $\begin{array}{c}\text { Center-left } \\
\text { coalition }\end{array}$ & $\begin{array}{c}\text { Center-right } \\
\text { coalition }\end{array}$ & $\begin{array}{c}\text { Five Star } \\
\text { Movement }\end{array}$ \\
\hline $\begin{array}{l}\text { Level of TV } \\
\text { exposure }\end{array}$ & & & \\
Low & $79 \%$ & $79 \%$ & $95 \%$ \\
High & $98 \%$ & $99 \%$ & $96 \%$ \\
$\begin{array}{l}\text { Politically active on } \\
\text { the Web }\end{array}$ & & \\
Low & & & \\
High & $89 \%$ & $86 \%$ & $94 \%$ \\
\hline
\end{tabular}

Table A.3. Three Categories of TV Viewership (\% of Respondents in the Sample in Parentheses).

\begin{tabular}{lccc}
\hline & $\begin{array}{c}\text { Center-left } \\
\text { coalition }\end{array}$ & $\begin{array}{c}\text { Center-right } \\
\text { coalition }\end{array}$ & $\begin{array}{c}\text { Five Star } \\
\text { Movement }\end{array}$ \\
\hline Low (43.4\%) & $39 \%$ & $58 \%$ & $63 \%$ \\
$\begin{array}{l}\text { Medium } \\
(29.2 \%)\end{array}$ & n.s. & $23 \%$ & $42 \%$ \\
High (27.2\%) & $68 \%$ & $26 \%$ & $83 \%$ \\
\hline
\end{tabular}

Appendix B. Descriptive statistics of independent variables included in the regression analysis

\begin{tabular}{|c|c|c|c|c|c|}
\hline & $N$ & Min. & Max. & Mean & $\begin{array}{l}\text { St. } \\
\text { Dev. }\end{array}$ \\
\hline \multicolumn{6}{|l|}{ Coalition leaders trait index } \\
\hline Pierluigi Bersani (center-left) & 868 & 0 & 1 & 0.63 & 0.33 \\
\hline Silvio Berlusconi (center-right) & 896 & 0 & 1 & 0.48 & 0.33 \\
\hline $\begin{array}{l}\text { Beppe Grillo (Five Star } \\
\text { Movement) }\end{array}$ & 746 & 0 & 1 & 0.62 & 0.36 \\
\hline \multicolumn{6}{|l|}{ Ideology } \\
\hline No self-placement & 950 & 0 & 1 & 0.09 & 0.29 \\
\hline Center-left & 950 & 0 & 1 & 0.58 & 0.49 \\
\hline Center-right & 950 & 0 & 1 & 0.33 & 0.47 \\
\hline \multicolumn{6}{|l|}{$\begin{array}{l}\text { Best coalition at most important } \\
\text { issue }\end{array}$} \\
\hline Center-left & 950 & 0 & 1 & 0.25 & 0.43 \\
\hline Center-right & 950 & 0 & 1 & 0.13 & 0.34 \\
\hline Five Star Movement & 950 & 0 & 1 & 0.14 & 0.35 \\
\hline Other & 950 & 0 & 1 & 0.14 & 0.35 \\
\hline $\begin{array}{l}\text { Retrospective economic } \\
\text { evaluations }\end{array}$ & 950 & 0 & 1 & 0.11 & 0.15 \\
\hline \multicolumn{6}{|l|}{ Age category } \\
\hline $18-24$ & 950 & 0 & 1 & 0.09 & 0.29 \\
\hline $25-34$ & 950 & 0 & 1 & 0.14 & 0.35 \\
\hline $35-44$ & 950 & 0 & 1 & 0.15 & 0.35 \\
\hline $45-54$ & 950 & 0 & 1 & 0.19 & 0.39 \\
\hline $55-64$ & 950 & 0 & 1 & 0.20 & 0.40 \\
\hline $65+$ & 950 & 0 & 1 & 0.23 & 0.42 \\
\hline Gender (female) & 950 & 0 & 1 & 0.49 & 0.50 \\
\hline Educational level & 950 & 0 & 1 & 0.43 & 0.25 \\
\hline \multicolumn{6}{|l|}{ Region of residence } \\
\hline North-West & 950 & 0 & 1 & 0.27 & 0.44 \\
\hline North-East & 950 & 0 & 1 & 0.13 & 0.34 \\
\hline Red Belt & 950 & 0 & 1 & 0.21 & 0.40 \\
\hline Center & 950 & 0 & 1 & 0.15 & 0.36 \\
\hline South & 950 & 0 & 1 & 0.24 & 0.43 \\
\hline Frequency of church attendance & 950 & 0 & 1 & 0.35 & 0.27 \\
\hline
\end{tabular}

Table A.4. One-by-One Exclusion of Items From the Measurement of Political Activity on the Internet.

\begin{tabular}{lcccccc}
\hline & $\begin{array}{c}\text { Center-left } \\
\text { coalition }\end{array}$ & \multicolumn{2}{c}{$\begin{array}{c}\text { Center-right } \\
\text { coalition }\end{array}$} & \multicolumn{2}{c}{$\begin{array}{c}\text { Five Star } \\
\text { Movement }\end{array}$} \\
& Min. & Max. & Min. & Max. & Min. & Max. \\
\hline Not active on the Internet & {$[55 \%$} & $57 \%]$ & {$[36 \%$} & $42 \%]$ & {$[52 \%$} & $54 \%]$ \\
Active on the Internet & {$[29 \%$} & $35 \%]$ & {$[$ n.s. } & n.s. $]$ & {$[64 \%$} & $70 \%]$ \\
\hline
\end{tabular}

